\title{
THE ANTHROPOLOGY OF CULTURAL HERITAGE IN \\ EUROPE
}

A BRIEF GENEALOGY FROM THE DESK (1970-2020) AND

EMPIRICAL OBSERVATIONS FROM THE FIELD (2010-2020)

\section{ALESSANDRO TESTA}

This article offers an overview of the origins and development of the anthropology of cultural heritage in Europe, tracing its main genealogical lineages stemming from kindred disciplines and methods in a comparative fashion. This briefgenealogy is then complemented by a set of considerations and observations about the author's personal ethnographic explorations of various European countries and regions, again with the aim of fruitful comparison. The article discusses how the anthropology of cultural heritage in Europe emerged, where it stands now, and where it might be going.

Keywords: cultural heritage, UNESCO, anthropology of cultural heritage, Europe, politics
$V$ članku je podan primerjalni pregled izvirov in razvoja antropologije kulturne dedišcine v Evropi in sledi glavnim genealoškim smerem, ki izvirajo iz sorodnih disciplin in metod. S ciljem plodovite primerjave kratko genealogijo dopolnjuje niz premislekov in opazovanj o avtorjevih etnografskih raziskavah $v$ različnih evropskih državah in pokrajinah. Avtor razpravlja o razlogih za vznik antropologije kulturne dedišcine v Evropi, njen trenutni položaj in morebitne poti $v$ prihodnje.

Ključne besede: kulturna dedišcina, Unesco, antropologija kulurne dedišcine, Evropa, politika

\section{INTRODUCTION*}

Janus bifrons is a good symbol to characterize the "retro-futurology" (Testa, 2020) of the heritage discourse and its dual, divergent trajectory along temporal axiality; a discourse that, like the Roman god Janus, looks simultaneously back at the past and forward to the future. In this article, this aspect is substantiated in a specific and narrower sense: by looking at how the anthropology of cultural heritage in Europe (ACHE) has emerged in the past few decades and where its future path might lead. First, however, it is necessary to dedicate a few words to the problematic field of investigation: Europe. ${ }^{1}$

Almost all European countries went through either a dictatorship or a military occupation between the 1920s and the 1940s. The subsequent Second World War resulted in a magnitude of material destruction that ultimately triggered, as has been studied extensively, a sense of urgency to safeguard that ample ensemble of things that, in the

* The author would like to thank the anonymous reviewers for their useful remarks, which helped improve this article, and especially Cyril Isnart and Valdimar Hafstein for sharing their wisdom through correspondence, which helped me better understand the development of the anthropology of cultural heritage in Europe.

1 Ethnologists and anthropologists are certainly aware what a tricky field Europe is to define and explore, with its vague or contested borders and ever-changing sociocultural textures made of intricate patterns of local variations, intertwining general trends, vernacular flairs within national traits, striking similarities, apparent uniformities, and evident or unexpected differences. 
following years, started to be conceived of and labeled as "heritage" (both "natural" and "cultural"). In other countries and regions, in Europe as well as elsewhere, the same sense of urgency had started to be felt even before; for instance, concerning the vanishing of peasant cultures vis-à-vis the radical changes triggered by modernization and the sense of cultural loss created by this cluster of sociocultural changes (Testa, 2018). UNESCO served the purpose of materializing and institutionalizing these urgencies by establishing the Convention Concerning the Protection of the World's Cultural and Natural Heritage in 1972. The heritage machinery resulting from the global trauma of the Second World War slowly became entangled with the different institutional perceptions and implementations of (and contributions to) the UNESCO schemes in different European countries, and it was very often paired up with-or developed in synergy with-nascent national schemes. The methodology, themes, and attitudes of the general public, of functionaries, and also of scholars working on heritage issues have been immensely influenced, in Europe as well as elsewhere, by the mindsets that emerged after the Second World War, although for a long time such influence remained somewhat unrecognized and under-researched. It is also necessary to emphasize that the anthropology of cultural heritage $(\mathrm{ACH})$ and the $\mathrm{ACHE}$ grew together, feeding on each other, in a constant interplay and fusion of national and transnational methodological trends, empirical insights, and theoretical shifts.

At any rate, a veritable history of the $\mathrm{ACH}$ in (or of) Europe is yet to be written. What follows is no exercise in disciplinary historiography for the simple fact that it does not dwell on the actual content of most of the studies it cites; nor does it aspire to exhaustiveness, although it does stem from historiographical and genealogical considerations that merge with the autobiographical remarks and ethnographic insights of a seasoned reader and researcher in this field, or rather subfield, of study. The following selection of studies is therefore inevitably partial and helplessly subjective, although I am inclined to believe that it does individuate certain rather factual (or even "objective") scholarly trends of the ACHE. ${ }^{2}$

\section{A BRIEF GENEALOGY FROM THE DESK}

When I personally became interested in cultural heritage from an anthropological perspective, in 2008, I was a master's student in historical sciences and comparative religions. Those were probably the central years, perhaps even the golden age, of the ACH. Some of the most influential studies were published in just a handful of years at that time (Noyes, 2006; Smith, 2006, 2007; Fourcade, 2007; Hemme, Tauschek, Bendix, 2007; Smith, Akagawa, 2009). These studies centered mostly, although not exclusively, on intangible cultural heritage (ICH). This should not be surprising, because those were the years of

2 Many of the works cited on the following pages are edited volumes, which contain often extraordinary shorter pieces (articles, chapters, forewords, and afterwords), which deserve separate mention, along with their authors. However, space does not permit this. 
an expectable surge of interest following the inception and ratification of the UNESCO ICH scheme (2003-2004).

In Italy and France, the countries where I was studying at the time, this was also the period when some of the most important studies in this young tradition of studies were being published, and moreover with a certain fervor (Fabre, 2000; Palumbo, 2003; Bravo, 2005; Clemente, 2005; Maffi, 2006; Fourcade, 2007). The field was young, but not in its infancy: European precursors interested in the salvaging, reenactment, and institutionalization of those forms of ritual and festive culture that would be later be labeled as $\mathrm{ICH}$ could already be found back in the 1970s (Gallini, 1971; Fabre, Camberoque, 1977), again in Italy and France, ${ }^{3}$ and especially in folklore studies, but the period of incubation of an ACHE "proper" was actually the 1980s. In the early 1980s, a great impact was made by what is today the canonical edited volume by Eric Hobsbawm and Terence Ranger (1983) about the invention of collective national traditions, and the likewise influential book from the same time by Michael Herzfeld (1982) about folklore and the politics of culture and national identity in Greece. A couple of years later, Richard Handler $(1985,1988)$ published a few equally noteworthy works about the institutionalization and patrimonialization of national culture in Quebec, Canada.

The 1990s, on the other hand, saw the advent of an ACH aware of being such (Fabre, 1994 and Kirshenblatt-Gimblett, 1995, are probably among the few studies to consciously initiate this trend, at least to my knowledge) as well as the ACHE "proper." In fact, it was in those years that the Netherlands and France provided an important contribution to the nascent field; namely, the important works by Jeremy Boissevain (1992), Daniel Fabre (1994), and Pierre Nora ${ }^{4}$ (1997). Not surprisingly, all of them were scholars with a strong penchant for history and historical anthropology, and they were also interested in both their own countries and Europe in a comparative fashion. History and archaeology indeed played a crucial role in these years, obviously not only in France, but elsewhere as well (Tunbridge, Ashworth, 1996; Poulot, 1997, 2001; Lowenthal, 1998), also because a strong interest in the understanding, preservation, promotion, and transmission of the past understandably already existed in these disciplines, thus laying the ground for the birth and development

3 There must certainly be other works and scholars belonging to other national traditions I am unaware of that also paved the way to-and alas remain lesser-known precursors of - the ACHE in the 1970s and the 1980s. I am more familiar with the Italian and French literature of that time. The fact that a precocious interest in the anthropological study of cultural heritage emerged in countries such as Italy and France is not surprising.

4 Pierre Nora was actually a historian and the author of a previous groundbreaking trilogy of historical books about French national identity, social memory, monumentalization, and heritagization, which popularized the notion of lieu de mémoire (1984-1992). Even though he has always remained rather skeptical of or uninterested in paradigms focusing on oral traditions, folklore, and later ICH, Nora had actually been working on the relationship between history, construction of the past, and collective memory since the 1970s and can therefore be considered one of the fathers of a lineage of fruitful cultural and historical reflections and works about heritage, which in a matter of a few years percolated from their place of origin, France, into western scholarship at large. 
of the $\mathrm{ACH}$ on the one hand, and on the other the future cross-pollination between these different disciplines. In fact, even today it is difficult at times to completely disentangle the discrete conceptual contributions of history, anthropology, archaeology, ethnology, and folklore studies in the development of the ACH and the ACHE.

Meanwhile, in the English-speaking world, Barbara Kirshenblatt-Gimblett published several groundbreaking works (1995, 1998), de facto initiating a new way and wave of thinking about heritage outside of Europe, but with a strong intellectual impact on European scholarly traditions as well (she then continued to publish many other influential works at the crossroads between museology, anthropology, folklore studies, and cultural studies). Whereas the French tradition had seen the ACHE feeding on the epistemological interactions between folklore studies and the nouvelle histoire, especially on topics of social memory, national identity, and regionalisms, in the overseas English-speaking world the new wave originated mostly from the interaction between folklore studies and museum studies, which developed in the late 1970s and the 1980s, flourishing during the 1990s. ${ }^{5}$ The mid-1990s also saw the foundation of the International Journal of Heritage Studies (1994), which on the one hand crowned this process of emergence and crystallization, and on the other produced a renewed impulse to further theorization and exploration into the meanders of a still young field of study.

The 1990s were the years of the foundation of the ACHE, and the 2000s saw a flourishing of new trends and authors. Germanic and northern European countries also became more active and visible in this new but increasingly wider subfield, often bringing fresh theoretical insights from other disciplines such as archaeology, ecology, and, again, museology (Silvén, 2018). This new momentum internationalized quickly and gained traction in the first five years of the decade (Bendix, 2000; Johler, 2002; Knecht, Niedermüller, 2003; Hafstein, 2004; Klein, Mathisen, Siikala, 2004), accelerated during the second half of the decade (Fourcade, 2007; Hemme, Tauschek, Bendix, 2007; Di Giovine, 2008; Nic Craith, 2008), and was consolidated between the end of the decade and the beginning of the next (Heinich, 2009; Tauschek, 2010; Adell, 2011; Bortolotto, 2011; Ballacchino, 2013). This era culminated in roughly 2011 to 2013, with the publication of Sharon Macdonald's comprehensive and authoritative Memorylands (2013), ${ }^{6}$ and a few other major recapitulative works (Bortolotto, 2011; Hottin, 2011; Imbriani, 2011; Tauschek, 2011, 2013; Hafstein, 2012; Heinich, 2012; Hertz, Chappaz-Wirthner, 2012; Berliner, Bortolotto, 2013; Harrison, 2013; see also several important chapters in Kockel, Nic Craith, Frykman, 2012). ${ }^{7}$

5 Museology and archaeology were of course also influential in the non-English-speaking world, and especially in France, but not, in my opinion, to the same extent as in the English-speaking world.

6 When I reviewed the book for Social Anthropology (Testa, 2014b), I had a feeling that much of what ethnology and the ACHE had to say had in fact already been said, and that that book was a sort of seal for the discipline. I was wrong, but only partly.

7 It is appropriate to recall here that these were the years that saw a revitalization of the SIEF (Societé Internationale d'Ethnologie et de Folklore), which had previously been somewhat less vital for some 
The years following the climax in 2011 to 2013 were years of proliferation and expansion, when several new research trajectories and problems were theorized or systematized about cultural heritage and ICH in Europe (Bendix, Eggert, Peselmann, 2013; Adell et al., 2015; Logan, Kockel, Nic Craith, 2015; Testa, 2016a), or further afield (Brumann, 2014, 2015; Testa, 2016b). In these years, eastern Europe and Slavic scholarship also started to play a greater role and be more represented and recognized in scholarship (Testa, 2016b). ${ }^{8}$ Indeed, it is rather hard to keep track of precisely what has been happening in the last ten years: in this time span, studies in the ACHE have multiplied exponentially and passed from the order of the tens to the hundreds, with dozens of research projects and entire cohorts of folklorists, ethnologists, and anthropologists producing generous published outputs. A contribution to this impulse, roughly in the last ten years, has also been given by the growing individuation of cultural heritage as a field of research per se by many funding agencies and schemes, thanks to which many scholars have been able to fund their research not only as ethnologists, anthropologists, musicologists, and so on, but also, and for the first time, as cultural heritage experts. National traditions in the ACHE have also been consolidated in these years, adding specific timbres and recognizable voices to a growingly diverse choir.

In recent years, the expansion has continued, particularly in the Europeanist field (Lähdesmäki, 2016; Clopot et al., 2019; Tornatore, 2019; Isnart, Testa, 2020b, to name a few edited volumes characterized by a comparative approach; ${ }^{9}$ otherwise, studies focusing on cultural heritage in individual European countries have become innumerable of late). The same trend characterizes the $\mathrm{ACH}$ in a global perspective, with newer and inspiring treatises and comparative or theoretical studies being published (Hafstein, 2020; Brumann, 2021; Cerezales, Isnart, 2021). This more recent spur might indeed represent the swan song of the entire field because there is a widespread sentiment in the academic community that both the ACH and its subfield the ACHE have said most of what they had to say: many scholars that have been working in this field for years, sometimes for decades, are understandably weary of it. My prognosis may be wrong, but a period of stagnation seems to be in the offing. It has at any rate become much more difficult to gain an overview of the entire field of late.

It might be interesting to note that these relatively well distinguishable phases in the development of the ACHE, which I already outlined (incubation, foundation, traction,

time. It is significant that the three individuals that presided over this revitalization were all recognized experts in cultural heritage: Regina Bendix (2001-2008), Ullrich Kockel (2008-2013), and Valdimar Hafstein (2013-2017), and so were also the executive vice-presidents from Bendix's second term until today: first Peter Jan Margry, and more recently Sophie Elpers. The circulation of knowledge and mutual strengthening of the ACHE and SIEF during these crucial years for the field (also through its flagship journals Ethnologia Europaea and Cultural Analysis) can hardly be overstated.

8 In 2013, the journal Muzeológia a kultúrne dedičstvo / Museology and Cultural Heritage was established in Slovakia.

9 Others have been (or are being) published since 2019 in the prolific Routledge series Critical Heritages of Europe. 
consolidation, acceleration, proliferation, expansion, and a possible forthcoming stagnation), were consummated within just a few decades: mainly from the 1990s (with a few precursors in the 1970s and 1980s) up until today (2021). This development seems to have run in parallel with that of the UNESCO schemes for cultural heritage and ICH. This does not come as a surprise to those familiar with the history and development of these schemes, and with the relationship between the taxonomic and epistemological frameworks and political agendas of the UNESCO and the academic and "etic" discourses that have both influenced them and been influenced by them. ${ }^{10}$ The ACHE as the product of a conceptual synergy and entanglement between anthropology, folklore studies, and museology has been initiated and has flourished in this wider, complex, and ultimately global framework-although it has ultimately been vernacularized and indigenized wherever it has been implemented, in Europe as well as elsewhere. There can be no true understanding of the ACHE today and in the past without and outside this framework.

\section{EMPIRICAL OBSERVATIONS FROM THE FIELD}

For generational reasons, I did not go through the main phases of the process outlined in the last few pages as a scholar; in fact, I have been active only during its last three or four phases. Nevertheless, the lesser vertical (temporal) depth of my research has probably been compensated by its horizontal (geographical) extension: I have chosen to focus on the history and anthropology of Europe comparatively and have acquainted myself with different traditions of studies and methodological sensibilities in the countries and regions in which I studied or worked (Italy, France, Estonia, Austria, Germany, and the Czech Republic) or where I was engaged in long-term, in-depth ethnographies (central-southern Italy in 2010-2012, Catalonia in 2016-2020, and Bohemia in 2013-2014 and 2019-2021). This personal trajectory has obviously had an impact on the kind of ACHE I have theorized and practiced. My fields and objects of investigations have also proven less conventional or even singular. The Czech Republic is a good example, as I am about to explain.

Taking the Second World War as a temporal watershed for the sake of periodization, as I also did at the beginning of this article, Italy's modern democracy is older (1948) than the Spanish (1979) and the Czech (or rather Czechoslovak, 1990). At first this characterization might seem secondary for what concerns the study of cultural heritage, but it is not, because the politics of culture-and the cultural heritage machinery is indeed a form of political governance of culture and things cultural—is indeed strongly connected with politics (and polity). The difference between Italy and Spain with respect to the politics of cultural heritage is, broadly speaking, relatively smaller, with Spain having implemented

10 The story of what I have named the "problematic filiation" from folklore to ICH is related in Testa 2016a. 
some of its most important schemes and reforms during the transition to democracy in the 1970s and 1980s (Testa, Vaczi, Forthcoming; Testa, Forthcoming) in close dialogue, just like Italy and France, with UNESCO. This synergy has proven successful because Italy is the country with the greatest number of UNESCO sites in the world, with Spain close behind. The Czech case, on the other hand, is emblematic, if not unique, for another reason: the Czech Republic has also been a successful country in terms of UNESCO recognition (the Czech Republic has fourteen cultural heritage sites and seven $\mathrm{ICH}$ elements on the list, a very high number for a country of ten million), but the UNESCO Cultural Heritage Convention was not ratified before the fall of communism (similar to most, although not all, other countries of the Eastern Bloc), and even the ICH Convention was ratified only very late, in 2008 - that is, five years after its inception. Before 1989, the kind of reforms but also conversations surrounding the now-taken-for-granted Western idea of cultural heritage as we know it were simply not happening on this side of the Iron Curtain. They were initiated only starting in the 1990s (i.e., significantly later than elsewhere in Europe), and it took some time for the engine of change to gain traction.

Today, such previous gaps are hardly perceivable, and at any rate they are unknown by the vast majority of the population, also because of the belated but comfortable honeymoon the Czech Republic and UNESCO have been enjoying for years now. Nonetheless, when I started studying the Czech case in 2013 - the carnival in the Hlinsko region, which has been listed as UNESCO ICH since 2010 (Testa, 2016a, 2016b, 2017a, 2017b) - I came across many tales and observations from my informants about how complicated building up the candidature had been during the 2000s, how long it had taken, and the extent of bureaucratic and political recalcitrance (or even plain ostracism, also at the highest institutional levels) to the idea of ICH being applied to and implemented in the country. Not surprisingly, the recognition of the carnival came rather late (2010), and just as late came, as already mentioned, the ratification of the 2003 convention (2008). This article is no place to describe the complex reasons behind such recalcitrance; this has already been done in my previously cited studies. My intention in evoking these particularities of the Czech case is justified only by the will to show how uneven the process of acceptance and implementation was on UNESCO's part at the time, even in countries with more recent accession to the EU, and which often hastened, in many other respects, to "Europeanize" and "Westernize" themselves as quickly as possible. This is an interesting variation, in my opinion, of cultural heritage-making in the "new" Europe.

The Catalan case has also been both exemplary and exceptional at the same time. After years of being preoccupied about the relationship between tradition and heritage, or about heritage as tradition, and about tradition being heritagized, this was a case that seemed to counter some of my previous working hypotheses and conclusions. In 1979, Solsona's carnival was declared by the Spanish government, despite its then emerging (and today solid) anti-Castilian stance, to be a fiesta de interés turistico nacional (festival of national tourism interest) — an official denomination that was copied a few years later by the Catalan 
parliament, or Generalitat). When this happened, it was a very young festival with just a handful of years of history: it began to be timidly performed in the early 1970s but only grew after Franco's death and the lifting of his prohibitions regarding the manifestation of Catalan culture and language. The carnival started to emerge as a mass phenomenon only during the second half of the 1970s and in the 1980s; that is, during the core period of the Spanish transition from the Francoist dictatorship to liberal democracy. It was basically a festival with no past, apart from some half-forgotten fragments from the pre-Francoist period. Unlike many "traditional" events in search of recognition and "wanting" to become heritage (Testa, 2019), this festivity had been transformed rather early, in a manner of speaking, into a piece of heritage, but without any veritable elements of historical continuity behind it. It was a heritage without a tradition.

If the Czech case was peculiar, and the Catalan one singular, the Italian one was also distinctive-or rather, just like the other ones, "normally exceptional." A carnivalesque ritual showing characteristic archaic traits, performed once a year in a mountainous region of southern-central Italy, the rito dell'Uomo-Cervo (ritual of the Deer-Man) in Castelnuovo al Volturno is widely known in the entire peninsula and has also been the object of a rich gray and non-professional literature, but also of widespread mediatization and of robust touristification (Testa, 2014a, 2016a, 2017a, 2017b, 2019, 2020). However, unlike the Czech carnival, which was recognized by UNESCO in 2010, and the Catalan Solsona carnival, which was recognized by both Spanish and Catalan institutions and given a national label already in the 1970s and 1980s, the rito has never made it into a national or international program, although it has been differently recognized as a meaningful tradition at the regional and provincial levels, and although it is widely considered a de facto piece of heritage by the locals. Broadly and figuratively speaking, if the Czech case was that of a heritagized tradition, and the Catalan that of a heritage without tradition, Castelnuovo was a case of a tradition without (official) heritagization. This is far, however, from making it not a piece of heritage, because cultural heritage does not exist only in the etic ivory tower and has also become, in time, a vernacularized category, as the now rich literature on the ACHE has shown over the years. Like for the majority of the thousands of European festivals and rituals, oral traditions, folk techniques and arts, and other elements of what we have come to think of as "heritage," an official recognition and a label are no longer necessary for people to feel "heritage emotions" (Heinich, 2012) and to implement protective or promotional initiatives concerning their most valuable traditions. In other words, cultural heritage has been embodied and naturalized as a common experiential dimension of the European peoples, and today it widely circulates as both an etic and emic category. The Italian case showed this pattern rather clearly already in the early 2000s and does so even more today.

The previous cursory overview of certain general aspects of my own research in matters related to cultural heritage in Europe modestly suggests that the ACHE is indeed a field of study united in and by the thriving diversity of its themes and topics, but also by the likewise copious variety of theoretical and methodological approaches established by the 
scholars that crowd it. The entanglements between institutional reforms concerning national culture and heritage, changing mentalities and attitudes about preserving worth from the past as heritage, the influence of transnational agencies like UNESCO that over time have come to be a veritable synonym of heritage, and the slow changes at the community level and at the meso-level of local representatives and functionaries are all some of the factors that created, in a matter of few decades, a brand new territory for scientific exploration. The relatively rapid growth and expansion of the ACHE should not be surprising: anthropology is a discipline methodologically well suited to unraveling such entanglements and interpreting the narrative and discursive shifts that have been occurring in the realm of all things patrimonial in the past few decades, making the filigree of the interwoven changes in public perception, usage, and "consumption" of heritage appear more clearly.

\section{CONCLUDING REMARKS}

ACHE is an ugly acronym used in this article for the sake of brevity. Its shortness and clumsiness, however justifiable, regrettably mask and actually flatten an important facet: there are indeed distinctions to be made within the semantic scope that such an acronym carries. ${ }^{11}$ First, there is, in fact, a European $\mathrm{ACH}$, one that is written by European scholars (such as David Berliner, Cristoph Brumann, Valdimar Hafstein, and several others) that have worked on cultural heritage in a global or transnational perspective (not surprisingly, focusing very often on UNESCO policies), and doing fieldwork or having a regional expertise also or especially in non-European or non-Western contexts. Second, there is also an anthropology of European cultural heritage, which focuses on European cases without the scholars involved having European national and (therefore) theoretical and methodological backgrounds. This class of researchers often bring a characteristic non-European "flair" to the type of anthropology they practice (Dorothy Noyes, Barbara Kirshenblatt-Gimblett, and Michael Di Giovine are good examples of this second typology). Third, and last but not least, and actually numerically the most prominent category, is the ACHE, by which I refer to the class of European scholars studying cultural heritage matters "at home" or in other European countries, and by doing so being both students and constitutional elements (consciously or unconsciously, intentionally or unintentionally) of that typically European "memory-heritage-identity complex," as Sharon Macdonald has named it (2013) — whether or not one might believe in this specific aspect of European "mentality" or "ethos" concerning history and the past and "our" place in them and construction and perception of them. The latter typology, to which I myself belong, is certainly the most populated in the realm

11 Again, for the sake of brevity, and in so doing operating an unfortunate but necessary epistemological stretch, I am subsuming ethnology and folklore studies under the label anthropology. 
of the ACHE. ${ }^{12}$ As anthropologists, ethnologists, and folklorists of cultural heritage from, in, or of Europe, we cannot but be part of this recent field, which, however, is now old enough to have a story of its own, a story that I have tried to briefly outline in this article.

\section{REFERENCES}

Adell, Nicolas. 2011. Le patrimoine, l'éthique, l'identité. La Ricerca Folklorica 64: 81-93.

Adell, Nicolas et al., eds. 2015. Between Imagined Communities and Communities of Practice: Participation, Territory and the Making of Heritage. Göttingen: Göttingen University Press. https://books.openedition.org/gup/208.

Ballacchino, Katia. 2013. Per un'antropologia del patrimonio immateriale: Dalle Convenzioni Unesco alle pratiche di comunità. Glocale 6-7: 17-32.

Bendix, Regina. 2000. Heredity, Hybridity and Heritage from One Fin de Siècle to the Next. In Folklore, Heritage Politics and Ethnic Diversity: Festschrift for Barbro Klein, eds. Pertti J. Anttonen et al., 37-54. Botkyrka: Multicultural Centre.

Berliner, David, and Chiara Bortolotto. 2013. Introduction: Le monde selon l'Unesco. Gradhiva 18: 4-21.

Boissevain, Jeremy, ed. 1992. Revitalizing European Rituals. London: Routledge.

Bortolotto Chiara. 2011. Introduction: Le trouble du patrimoine culturel immatériel. In Le patrimoine culturel immatériel: Enjeux d'une nouvelle catégorie, ed. Chiara Bortolotto, 21-43. Paris: Maison des Sciences de l'homme.

Bravo, Gian Luigi. 2005: La complessità della tradizione: Festa, museo e ricerca antropologica. Milan: Franco Angeli.

Brumann Christoph. 2014. Heritage Agnosticism: A Third Path for the Study of Cultural Heritage. Social Anthropology 22 (2): 173-188. DOI: https://doi.org/10.1111/1469-8676.12068.

Brumann, Christoph. 2015. Cultural Heritage. In International Encyclopedia of the Social \& Behavioral Sciences 5, ed. James D. Wright, 414-419. Oxford: Elsevier.

Cerezales, Nathalie, and Cyril Isnart, eds. 2021. The Religious Heritage Complex: Legacy, Conservation, and Christianity. London, Oxford: Bloomsbury

Clemente Pietro. 2005. Oltre l'orizzonte. In Cultura popolare e mondo tecnologico, 235-270. Napoli: Guida. [Italian translation of: Hermann Bausinger. 1961. Volkskultur in der technischen Welt. Stuttgart: Kolhammer.]

Di Giovine, Michael. 2008. The Heritage-scape: UNESCO, World Heritage, and Tourism. Lanham: Lexington Books.

Fabre, Daniel. 1994. Ethnologie et patrimoine en Europe. Terrain 22: 145-150.

Fabre, Daniel. 2000. Domestiquer l'histoire: Ethnologie des monuments historiques. Paris: Éd. de la Maison des sciences de l'homme.

12 These three typologies doubtlessly form the majority of the ACHE for how it has developed since its inception. Other subcategories or sub-typologies could be formed, of course, but, as I state at the beginning of this article, exhaustiveness is not among my aims in this article, and I therefore willingly save this exercise for another, future endeavor. 
Fabre Daniel, and Charles Camberoque. 1977. La Fête en Languedoc: Regards sur le carnaval aujourd'hui. Toulouse: Privat.

Gallini Clara. 1971. Il consumo del sacro: Feste lunghe di Sardegna. Bari: Laterza.

Fourcade, Marie-Blanche, ed. 2007. Patrimoine et patrimonialisation: Entre le matériel e l'immatériel. Laval: PUL.

Frykman, Jonas, Ullrich Kockel, and Máiréad NicCraith, eds. 2012. Companion to the Anthropology of Europe. Chichester: Wiley-Blackwell.

Hafstein, Valdimar Tr. 2004. The Making of Intangible Cultural Heritage: Tradition and Authenticity, Community and Humanity. Doctoral Dissertation. University of Berkeley.

Hafstein, Valdimar Tr. 2012. Cultural Heritage. In A Companion to Folklore, eds. R. Bendix and G. HasanRokem, 500-519. Malden: Wiley.

Hafstein, Valdimar Tr., and Martin Skrydstrup. 2020. Patrimonialities. Cambridge: Cambridge University Press.

Handler, Richard. 1985. On Having a Culture: Nationalism and the Preservation of Quebec's Patrimoine. In Objects and Others: Essays on Museum and Material Culture, ed. George W. Stocking, 192-217. Madison: The University of Wisconsin Press.

Handler, Richard. 1988. Nationalism and the Politics of Culture in Quebec. Madison: The University of Wisconsin Press.

Harrison, Rodney. 2013. Heritage: Critical Approaches. New York: Routledge.

Heinich, Nathalie. 2009. La fabrique du patrimoine: De la cathédrale à la petite cuillère. Paris: Éditions de la Maison des sciences de l'homme.

Heinich, Natalie. 2012. Les émotions patrimoniales: De l'affect à l'axiologie. Social Anthropology 20 (1): 19-33. DOI: https://doi.org/10.1111/j.1469-8676.2011.00187.x.

Hertz, Ellen, and Suzanne Chappaz-Wirthner. 2012. Le patrimoine a-t-il fait son temps? In Ethnographiques. org: Revue en ligne de sciences humaines et sociales 24. https://www.ethnographiques.org/2012/ Hertz-Chappaz-Wirthner.

Herzfeld, Michael. 1982. Ours Once More: Folklore, Ideology, and the Making of Modern Greece. Chicago: University of Chicago Press.

Hemme, Dorothe, Michael Tauschek, and Regina Bendix, eds. 2007. Prädikat "Heritage": Wertschöpfungen aus kulturellen Ressourcen. Münster: LIT.

Hobsbawm Eric J., and Terence Ranger, eds. 1983. The Invention of Tradition. Cambridge: Cambridge University Press.

Hottin, Christian, ed. 2011. Lepatrimoine culturel immatériel: Premières expériences en France. Paris: Maison des Cultures du Monde e Babel.

Imbriani, Eugenio. 2011. I beni culturali immateriali: Da folklore a patrimonio. Italianieuropei 2: 1-5.

Isnart, Cyril, and Alessandro Testa, eds. 2020. Re-enchantment, Ritualization, Heritage-making: Processes Reconfiguring Tradition in Europe. Monographic issue of Ethnologia Europaea 50 (1). https:// ee.openlibhums.org/issue/303/info.

Johler, Reinhard. 2002. The EU as Manufacturer of Tradition and Cultural Heritage. In Culture and Economy, ed. Ullrich Kockel, 223-223. Aldershot: Ashgate.

Klein, Barbro, Stein R. Mathisen, and Anna-Leena Siikala, eds. 2004. Creating Diversities: Folklore, Religion and the Politics of Heritage. Helsinki: Finnish Literature Society. 
Kirshenblatt-Gimblett, Barbara. 1995. Theorizing Heritage. Ethnomusicology 39 (3):367-380. DOI: https:// doi.org/10.2307/924627.

Kirshenblatt-Gimblett, Barbara. 1998. Destination Culture: Tourism, Museums, and Heritage. Berkeley: University of California Press.

Knecht Michi, and Peter Niedermüller. 2002. The Politics of Cultural Heritage: An Urban Approach. Ethnologia Europaea 32 (2): 89-104. DOI: https://doi.org/10.16995/ee.933.

Lähdesmäki, Tuuli. 2016. Politics of Tangibility, Intangibility, and Place in the Making of a European Cultural Heritage in EU Heritage Policy. International Journal of Heritage Studies 22 (10): 766-780. DOI: https://doi.org/10.1080/13527258.2016.1212386.

Logan, William, Ullrich Kockel, and Máiréad Nic Craith. 2015. The New Heritage Studies: Origins and Evolution, Problems and Prospects. In A Companion to Heritage Studies, eds. William Logan, Máiréad Nic Craith and Ullrich Kockel, 1-25. Malden: Wiley.

Logan, William, Máiréad Nic Craith, and Ullrich Kockel, eds. 2015. A Companion to Heritage Studies. Chichester: Wiley-Blackwell.

Lowenthal, David. 1998. Fabricating Heritage. History and Memory 10 (1): 5-24. https://www.jstor.org/ stable/i25681016.

Maffi, Irene, ed. 2006. Il patrimonio culturale. Roma: Meltemi.

Macdonald, Sharon. 2013. Memorylands: Heritage and Identity in Europe Today. London, New York: Routledge.

Nic Craith, Máiréad. 2008. Intangible Cultural Heritages: The Challenges for Europe. Anthropological Journal of European Cultures 17 (1): 54-73.

Nora, Pierre, ed. 1984-1992. Les Lieux de mémoire. 3 Vols. Paris: Gallimard.

Nora, Pierre, ed. 1997. Science et conscience du patrimoine. Paris: Fayard.

Noyes, Dorothy. 2006. The Judgment of Solomon: Global Protections for Tradition and the Problem of Community Ownership. Cultural Analysis 5: 27-56.

Palumbo, B. 2006 (2003). L'UNESCO eil campanile:Antropologia, politica e beni culturali in Sicilia orientale. Roma: Meltemi.

Poulot, Pierre Maurice. 1997. Musée, nation, patrimoine, 1789-1815. Paris: Gallimard.

Silvén, Eva. 2018. Museums, Museology and Cultural Heritage Studies in Sweden 1993-2017. Nordisk Museologi 25 (1): 119-129.

Smith, Laurajane. 2006. Uses of Heritage. London: Routledge.

Smith, Laurajane. 2007. Cultural Heritage: Critical Concepts in Media and Cultural Studies. London: Routledge, Taylor \& Francis Group.

Smith, Laurajane, and Natsuko Akagawa, eds. 2009. Intangible Heritage. London, New York: Routledge.

Tauschek, Markus. 2010. Cultural Property as a Strategy: The Carnival of Binche, the Creation of Cultural Heritage and Cultural Property. Ethnologia Europaea 39 (2): 67-80. DOI: https://doi.org/10.16995/ ee.1056.

Tauschek, Markus. 2011. Reflections on the Metacultural Nature of Intangible Cultural Heritage. Journal of Ethnology and Folkloristics 5 (2): 49-64. https://www.jef.ee/index.php/journal/article/view/76.

Tauschek, Markus. 2013. Kulturerbe: Eine Einführung. Berlin: Reimer.

Testa, Alessandro. 2014a. Il carnevale dell'uomo-animale: Le dimensioni storiche e socio-culturali di una festa appenninica. Napoli: Loffredo. 
Testa, Alessandro. 2014b. Review of Memorylands: Heritage and Identity in Europe Today by S. Macdonald. Social Anthropology/Anthropologie Sociale 22 (4):512-513.DOI: https://doi.org/10.1111/1469-8676.12092_20.

Testa, Alessandro. 2016a. From Folklore to Intangible Cultural Heritage: Observations about a Problematic Filiation. Osterreichische Zeitschrift fur Volkskunde 119 (34): 183-204.

Testa, Alessandro. 2016b. Problemi e prospettive della ricerca demo-etno-antropologica su memoria sociale, (n)ostalgia, ritualità pubblica e patrimonio culturale immateriale nell'Europa post-socialista. Lares 82 (2): 237-276.

Testa, Alessandro. 2017a. "Fertility" and the Carnival 1: Symbolic Effectiveness, Emic Beliefs, and the Re-enchantment of Europe. Folklore 128 (1): 16-36.

Testa, Alessandro. 2017b. "Fertility" and the Carnival 2: Popular Frazerism and the Reconfiguration of Tradition in Europe Today. Folklore 128 (2): 111-132.

Testa, Alessandro. 2018. Les « derniers » et leurs « saveurs » : Mythe culturel, discours académique, et/ou réalité historique?. Paper for the seminar "Apocalypses, salut et sauveurs culturels. Anthropologie des activistes patrimoniaux". Tourtour: Fondation des Treilles.

Testa, Alessandro. 2019. Events that want to become Heritage: On the Vernacularisation of ICH and the Politics of Culture and Identity in Public Rituals. In Heritage and Festivals in Europe, eds. Cristina Clopot et al., 79-94. London: Routledge.

Testa, Alessandro, 2020. "Retro-futurology”, ICH, and European Complex(iti)es. Paper for the Fifth Association of Critical Heritage Studies Biannual Conference Future. London.

Testa, Alessandro. Forthcoming. The Ritual Making of Central Catalonia 1: National Identity and the Hanging of the Donkey. In Culture, Identity, and Politics in Contemporary Catalonia, eds. Alessandro Testa and Mariann Vaczi. Cultural Analysis.

Testa, Alessandro, and Mariann Vaczi, eds. Forthcoming. Culture, Identity, and Politics in Contemporary Catalonia. Monographic Issues of Cultural Analysis.

Tornatore, Jean-Louis, ed. 2019. Le patrimoine comme expérience: Implications anthropologiques. Paris: Maison des Sciences de l'Homme.

Tunbridge, John E, and Gregory J. Ashworth. 1996. Dissonant Heritage: The Management of the Past as a Resource in Conflict. Chichester: Wiley.

\section{ANTROPOLOGIJA KULTURNE DEDIŠČINE V EVROPI: KRATKA GENEALOGIJA S PISALNE MIZE (1970-2020) IN EMPIRIČNA OPAŽANJA S TERENA (2010-2020)}

Razprava ponuja na eni strani pregled nastanka in razvoja antropologije kulturne dedišcine v Evropi, na drugi pa primerja in sledi glavnim smerem sorodnih disciplin in metod. Pri tem je pogled usmerjen najprej na pojav antropologije kulturne dedišcine v Evropi v zadnjih desetletjih in $v$ premislek o mogočih prihodnjih zastavkih in usmeritvah.

Splošna in evropska antropologija kulturne dediščine sta nastajali v nenehnem prepletu in zlivanju nacionalnih in transnacionalnih metodoloških teženj, empiričnih spoznanj in teoretskih 
premikov. Med pomembnimi avtorji velja omeniti Jeremyja Boissevaina (1992), Daniela Fabra (1994), Barbaro Kirshenblatt-Gimblett (1995) in Pierra Noraja (1997).

$V$ angleško govorečem svetu je Barbara Kirshenblatt-Gimblett objavila več prelomnih del (1995, 1998), ki so sprožila nov način in val razmišljanja o dedišcini zunaj Evrope in pomembno vplivala na evropske znanstvene tradicije. In če je francoska tradicija videla, da se antropologija kulturne dediščine v Evropi napaja iz epistemoloških interakcij med folklorističnimi študijami in novo zgodovino, zlasti s temami družbenega spomina, nacionalne identitete in regionalizmov, je v čezmorskem angleško govorečem svetu novi val izviral predvsem iz stikov med folkloristiko in muzejskimi raziskavami. V začetku drugega desetletja tega stoletja so bile teoretizirane ali sistematizirane nove raziskovalne poti in problemi (Bendix, Eggert, Peselmann, 2013; Bondaz et al., 2014). Za zadnje desetletje pa je značilno, da je kulturna dediščina kot raziskovalno področje deležna posebnega zanimanja številnih agencij in shem financiranja.

Avtor se v razpravi osredini na zgodovino in antropologijo Evrope in na razlicne raziskovalne tradicije $v$ državah, v katerih je študiral ali raziskoval (Italija, Francija, Estonija, Avstrija, Nemčija, Katalonija v Španiji in Češka). Pri odkrivanju in upravljanju kulturne dediščine je pomembno dejstvo, da gre za politiko kulture, ki je kot mehanizem kulturne dediščine pravzaprav oblika njenega političnega upravljanja in kot taka res močno povezana s politiko.

Prepletenosti med institucionalnimi reformami $v$ zvezi z nacionalno kulturo in dedišcino, spreminjanjem miselnosti in stališč do ohranjanja vrednosti iz preteklosti kot dediščine, vplivom transnacionalnih agencij, npr. Unesca, ki so sčasoma postale pravi sinonim za dedišcino, ter počasnimi spremembami na ravni skupnosti in na mezoravni lokalnih predstavnikov in funkcionarjev, vse to so dejavniki, ki so v nekaj desetletjih ustvarili povsem novo prizorišč za znanstveno raziskovanje.

V semantičnem pogledu je primerno razločiti tri diskurze antropologije kulturne dedišcine. Najprej gre za evropsko antropologijo kulturne dediščine, kakor o njej razpravljajo evropski raziskovalci, npr. David Berliner, Cristoph Brumann, Valdimar Hafstein idr.; ti obravnavajo kulturno dedišcino z globalnega ali transnacionalnega vidika (pogosto so zelo pozorni na Unescovo politiko), raziskujejo tudi na terenu ter imajo regionalno strokovno znanje, tudi ali zlasti iz neevropskih ali nezahodnih kontekstov. Drugič, obstaja tudi antropologija evropske kulturne dediščine, ki se osredinja na evropske primere, ne da bi vpleteni znanstveniki imeli evropsko nacionalno in (torej) teoretično in metodološko ozadje (npr. Dorothy Noyes, Barbara Kirschenblatt-Gimblett, Michael di Giovine). Tretja, po številu najopaznejša skupina in hkrati kategorija, ki predstavlja antropologijo kulturne dediščine v Evropi, pa so evropski raziskovalci, ki obravnavajo vprašanja kulturne dediščine "doma "ali v drugih evropskih državah; so hkrati raziskovalci in konstitutivni členi za značilno evropski "kompleks spomin-dediščina-identiteta" (Macdonald, 2013).

Assist. Prof. Dr. Alessandro Testa, Charles University Prague, alessandro.testa@fsv.cuni.cz 